\title{
PENERAPAN METODE PEMBELAJARAN MOTORIK PADA ANAK USIA DINI DI RA DWP IAIN PALU
}

\author{
Kasmiati
}

\begin{abstract}
Gross motor development in children is one of the important aspects that need to be considered by educators and parents. Children who have good gross motor skills will make it easier to get along with their friends. The children will be able to be good in the association. This research was used Class Action Research (CAR) approach by describing the motor learning process. The data collection was used observation and documentation. The rubric of children assessment contains 3 aspects of balance, Jumping (strength), and body agility, using 4 categories there are: Very Good Developing (VGD), Developing as Expected (DE), Starting to Develop (SD), Not Developing (ND), Data analysis is carried out from observations obtained through observation sheets in cycles I and II, after the data collected is to analyzed qualitatively to find out the process of action, then the data is processed using presentation techniques, the processed results are then analyzed descriptively to determine the presentation of the success of the action. The results shows that based on data analysis the results of the discussion that through motor learning methods can improve children's gross motor skills, in Pre-Action, The body balance aspects of the children, the category for VGD 10\%, DE 10\%, SD 5\%, and for ND 30\%. The strength aspects the body of children, the category for VGD $5 \%, D E 15 \%, S D 20 \%$, and for ND 30\%. The body agility aspects for children, the category for VGD $10 \%, D E 15 \%, S D 1 \%$, and for ND 50\%. After taking action using APE in cycle I, the child's gross motor ability increased, the child increased even though it was not as expected. By finished all the weaknesses in cycle I, the action is continued to cycle II, and the results of observation in cycle II show there is a good improvement, The body balance aspects of the children VGD categories 30\%, DE 45\%, SD 15\%, ND 10\%, The strength aspects the body of childres, VGD categories 5\%, DE 40\%, SD 20\%, ND $15 \%$. The body agility aspects for children, VGD categories $5 \%, D E 40 \%$, SD $20 \%$, and for ND $15 \%$. Peningkatan gross motor child of cycle I to cycle II, for VGD categories increased to 11,7\%, for DE increased to $13,4 \%$, for $S D$ increased to 1,7\%, for ND increased to 7,8 \%.
\end{abstract}

Keywords : Method, Motor Learning, Early Childhood.

\section{PENDAHULUAN}

Pendidikan Anak Usia Dini merupakan salah satu tahapan pendidikan

yang tidak dapat diabaikan karena ikut menentukan perkembangan dan 
166 | MUSAWA, Vol. 11 No. 2 Desember 2019 : 165 - 201

keberhasilan anak. Seiring perkembangan pemikiran tersebut, tuntutan, dan kebutuhan layanan pendidikan anak usia dini yang cenderung semakin meningkat dan berpengaruh pada kualitas penyelenggaraan lembaga pendidikan anak usia dini, termasuk lembaga pendidikan Taman Kanak-Kanak (TK) / Raudhatul Athfal (RA).

Melihat hal tersebut maka guru harus mampu menciptakan suasana pembelajaran yang menarik dan menyenangkan bagi anak. Hal ini di sebabkan karna penggunaan metode pembelajaran yang menarik bagi anak usia dini adalah salah satu faktor yang penting untuk membuat anak tertarik dalam belajar. Dengan lingkungan belajar yang menyenangkan dan bermakna bagi anak akan menambah dorongan anak agar belajar lebih giat. Selain itu, rentang perhatian anak Taman Kanak-Kanak (TK) sangatlah terbatas dan masih sulit oleh karena itu, guru harus mampu melakukan proses pembelajaran dalam suasana pembelajaran yang menyenangkan, misalnya dalam suasana bermain, maka anak tidak akan menyadari bahwa dalam kegiatan bermain tersebut sebenarnya anak sudah belajar.

Bermain merupakan dunia bagi anak yang menimbulkan kesenangan dan kepuasan, serta dapat mengembangkan sebagian besar potensi dalam dirinya. Pertumbuhan dan perkembangan sel syaraf pada anak akan mempengaruhi kinerja otaknya yang akan berfungsi untuk pemenuhan kebutuhan anak, misalnya pertumbuhan dan perkembangan kemampuan motorik kasar anak. Keterampilan motorik kasar pada anak tidak akan berkembang melalui kematangan begitu saja, melainkan juga keterampilan itu harus dipelajari. Maka sejak usia dini dalam pengembangan motorik kasar anak diperlukan kegiatan-kegiatan yang menyenangkan dan dapat menstimulus perkembangan motorik kasar anak.

Pemberian stimulasi pada anak usia dini sangat penting bagi perkembangan anak selanjutnya. Hal ini di sebabkan karena masa usia dini merupakan masa peka bagi anak dalam menerima rangsangan atau stimulus. Salah satu aspek perkembangan yang harus di stimulasi pada anak usia dini 
adalah kemampuan motorik kasar. Kemampuan ini berhubungan dengan kecakapan anak dalam menggerakan bagian tubuhnya yang besar, seperti tangan dan kaki, seperti keseimbangan tubuh, kekuatan tubuh dan kelincahan tubuh.

Berdasarkan proses perkembangan anak agar dapat tumbuh dan berkembang secara optimal maka membutuhkan pembinaaan dan pemberian rangsangan dan hal-hal yang dapat dilakukan melalui berbagai macam metode, salah satunya adalah metode bermain karena anak mampu menerima berdasarkan pengalaman belajar melalui permainan.

Di Raudhatul Athfal Dharma Wanita Persatuan IAIN Palu, penulis menemukan beberapa masalah, dalam kemampuan motorik kasar anak misalnya anak masih sering terjatuh atau masih kurang seimbang, anak masih kurang kuat, dan anak masih kurang lincah, Hal ini disebabkan karena masih kurangnya metode bermain yang dapat merangsang kemampuan motorik kasar anak. Mengingat pentingnya motorik kasar anak bagi perkembangan anak.

Lingkungan belajar yang menyenangkan dan bermakna bagi anak akan menambah dorongan anak agar belajar lebih giat. Selain itu, rentang perhatian anak Taman Kanak-kanak sangatlah berbatas dan masih sulit untuk melakukan proses pembelajaran dalam suasana pembelajaran yang menyenangkan, misalnya dalam suasana bermain, maka anak tidak akan menyadari bahwa dalam kegiatan bermain tersebut sebenarnya anak sudah belajar.

Pemberian stimulasi pada anak usia dini sangat penting bagi perkembangan anak selanjutnya. Hal ini di sebabkan karena masa usia dini merupakan masa peka bagi anak dalam menerima rangsangan atau stimulus. Salah satu aspek perkembangan yang harus di stimulasi pada anak usia dini adalah kemampuan motorik kasar. Kemampuan ini berhubungan dengan kecakapan anak dalam menggerakan bagian tubuhnya yang besar, seperti tangan dan kaki. seperti keseimbangan tubuh, kekuatan tubuh dan kelincahan tubuh.

Berdasarkan keunikan dan perkembangan anak terbagi beberapa menjadi tiga tahapan yaitu masa bayi, masa balita, masa pra sekolah, dan masa kelas 
168 | MUSAWA, Vol. 11 No. 2 Desember 2019 : 165 - 201

awal.anak yang berada dalam pertumbuhan dan perkembangan yang bersifat unik "yaitu pola pertumbuhan dan perkembangan (koordinasi mmotorik kasar dan halus), intelegensi (daya pikir), daya cipta, kecerdasan emosi dan kecerdasan spritual, sosial emosional (sikap dan prilaku serta agama), bahasa dan komunikasi anak perlu disesuaikan dengan tingkat pertumbuhan dan perkembangan”.

Perkembangan motorik kasar pada anak adalah salah satu aspek penting yang harus di perhatikan oleh guru dan orang tua. Anak yang memiliki kemampuan motori kasar yang baik akan lebih baik dalam bergaul dengan teman-temannya. Gerakannya lebih terkoordinasi dan membuat anak tampil lebih percaya diri. Hal ini akan membuat anak mampu bersikap baik dalam pergaulannya. Selain itu, koordinasi gerakan yang baik akan membantunya menampilkan sikap perencanaan yang baik. Ini akan membuat anak semakin terampil dalam menyelesaikan pesoalan sehari-hari yang di hadapinya.

Mengingat pentingnya pendidikan masa kanak-kanak sebagai pondasi awal pertumbuhan dan perkembangan mereka di masa mendatang, maka optimalisasi pendidikan di tiga lingkungan yaitu keluarga, masyarakat dan sekolah menjadi sangat penting. Aspek-aspek yang di kembangkan dalam hal ini di antaranya aspek fisik, sosial, emosional, dan kognitif anak saling berkaitan dan mempengaruhi satu sama lain.

Berdasarkan prosesnya, agar anak dapat tumbuh dan berkembang secara optimal maka membutuhkan pembinaaan dan pemberian rangsangan dan hal-hal yang dapat di lakukan melalui berbagai macam permainan, karena dunia anak adalah dunia bermain, bagi anak kegiatan bermain selalu menyenangkan, dan bermain juga mempunyai manfaat yang besar bagi perkembangan anak secara keseluruhan.

Metode pembelajaran motorik juga dapat mengembangkan fisik motorik anak di samping itu juga dapat menumbuhkan keakraban di lingkungan mereka, metode pembelajarann motorik juga melatih anak untuk menghargai pendapat orang dan sebuah perbedaan. metode pembelajarann motorik sangat bagus untuk 
membantu kepribadian anak. Sebab, dalam metode pembelajaran motorik terdapat unsur-unsur positif yang sangat membantu agar anak menjadi mandiri.

\section{PEMBAHASAN}

\section{Kemampuan Motorik Kasar}

Kemampuan motorik kasar anak di harapkan dapat terjadi secara optimal karena secara langsung maupun maupun tidak langung, akan mempengaruhi perilaku anak sehari-hari. Pertumbuhan motorik kasar anak mempengaruhi keterampilannya dalam bergerak.

Hurlock, mengungkapkan bahwa perkembangan motorik berarti perkembangan gerakan jasmani melalui kegiatan pusat syaraf, urat syaraf, dan otot terkoordinasi. Tanpa adanya perkembangan motoric, maka anak akan tetap tidak berdaya bagaikan bayi yang lahir. ${ }^{1}$ Perkembangan motorik dapat berjalan dengan baik, jika anak diberikan kesempatan untuk melatih keterampilannya menggunakan tubuh sendiri seperti berjalan, berlari, melompat, memegang, meraba, berbicara, dan lainnya.

Selanjutnya pertumbuhan dan perkembangan motorik kasar anak, akan mempengaruhi cara anak memandang diri sendiri dan orang lain. Hal itu dapat di lihat dari pola penyesuaian diri si anak secara umum, seperti anak kurang terampil melompat akan cepat sadar dirinya tidak mampu mengikuti prmainan tradisional batok kelapa seperti yang dilakukan teman-temannya.

Menurut John W.Santrock, bahwa "Kemampuan motorik kasar dan aktivitas lain berkembang memerlukan kontrol posisi tubuh”. Kemampuan motorik kasar adalah kemampuan motorik yang melibatkan aktivitas otot yang besar, seperti berjalan. $^{2}$ Kemampuan motorik kasar adalah kemampuan motorik yang melibatkan aktivitas otot yang besar, seperti berjalan, berlari, dan melompat.

Tingkat pencapaian perkembangan motorik kasar anak usia 5-6 tahun dalam PERMENDIKBUD Nomor 137 Tahun 2014 yaitu melakukan gerakan tubuh

\footnotetext{
${ }^{1}$ Elisabeth B Hurlock, Perkembangan anak Jilid I. (Terjemahan: Med Meitasari Tjandrasa bad Muchlihan Zarkasih). Jakarta: PT. Gelora Aksara Pratama. 2006, 63

2John W. Santrock, Life-Span Development (Perkembangan Masa Hidup),: (Edisi;5, Jakarta: Erlangga), 2002, 210
} 
170 | MUSAWA, Vol. 11 No. 2 Desember 2019 : 165 - 201

secara terkordinasi untuk melatih kelenturan, keseimbangan, dan kelincahan, melakukan koordinasi gerakan mata-kaki-tangan-kepala dalam menirukan tarian atau senam; melakukan permainan fisik dengan aturan terampil; menggunakan tangan kanan dan kiri; melakukan kegiatan kebersihan diri. $^{3}$

Kemampuan motorik kasar pada setiap anak mengalami perbedaan, ada anak yang mengalami kemampuan motoriknya sangat baik seperti yang dialami para atlet, tetapi ada anak yang mengalami keterbatasan. Selain itu juga dipengaruhi adanya jenis kelamin, kemampuan motorik dilihat dari perubahan fisik dan fsikis sesuai dengan masa pertumbuhannya, kemampuan motorik juga dipengaruhi oleh asupan gizi.

John W.Santrock, mengungkapkan bahwa "keterampilan motorik kasar (gross motor skills) meliputi kegiatan otot-otot besar seperti menggerakan lengan dan berjalan. Sedangkan, keterampilan motorik halus (fine motor skills) meliputi gerakan-gerakan menyesuaikan secara lebih halus, seperti ketangkasan jari”. Kemampuan motorik kasar adalah aktivitas yang menggunakan otot-otot besar, meliputi gerak dasar lokomotor, non lokomotor, dan manipulatif. ${ }^{4}$

Hurlock mengungkapkan bahwa perkembangan motorik berarti perkembangan gerakan jasmani melalui kegiatan pusat syaraf, urat syaraf, dan otot terkoordinasi. ${ }^{5}$ Tanpa adanya perkembangan motorik, maka anak akan tetap tidak berdaya bagaikan bayi yang lahir. Perkembangan morotik dapat berjalan dengan baik, jika anak diberikan kesempatan untuk melatih keterampilanya menggunakan tubuhnya sendiri seperti berjalan, berlari, melompat, memegang, meraba, berbicara, dan lainnya.

Berdasarkan beberapa pengertian kemampuan motorik kasar tersebut, dapat disimpulkan bahwa kemampuan motorik kasar adalah kemampuan yang memanfaatkan otot-otot besar tubuh untuk melakukan sutu gerakan pada seluruh tubuh sedangkan, perkembangan motorik adalah proses tumbuh kembang

${ }^{3}$ PERMENDIKBUD nomor 137 tahun 2014, Tentang Standar Nasional Pendidikan Anak Usia Dini.

${ }^{4}$ John W. Santrock., 145

${ }^{5}$ Elizabeth, B. Hurlock, Perkembangan Anak jilid I. (Terjemahan: Med Meitasari Tjandrasa bad Muchlihah Zarkasih). Jakarta: PT. Gelora Aksara Pratama., 2006, 63 
kemampuan gerak seseorang yang pada dasarnya, berkembang sejalan dengan kematangan syaraf otak dan otot.

\section{Tujuan Pendidikan Anak Usia Dini}

Secara umum tujuan pendidikan anak usia dini hampir sama dengan tujuan pendidikan nasional yaitu memberikan stimulasi atau rangsangan bagi perkembangan potensi anak, agar anak kelak bisa menjadi insan yang beriman dan bertaqwa kepada Allah swt, berakhlak mulia, sehat, berilmu, cakap, kritis, kreatif, inovatif, mandiri, percaya diri, dan menjadi warga Negara yang demokratis dan bertanggung jawab.

Senada dengan tujuan diatas, Solehuddin menyatakan bahwa tujuan pendidikan anak usia dini ialah memfasilitasi pertumbuhan dan perkembangan anak secara optimal dan menyeluruh sesuai dengan nilai-nilai kehidupan yang dianut. $^{6}$

Berdasarkan dua penjelasan diatas dapat disimpulkan bahwa tujuan pendidikan anak usia dini yaitu:

a. Mempersiapkan anak untuk memasuki pendidikan lebih lanjut.

b. Meningkatkan taraf kecerdasan anak.

c. Menigkatkan kualitas pendidikan.

d. Mengatasi tingkat kenaikan angka buta huruf.

\section{Urgensi Pendidikan Anak Usia Dini}

Berdasarkan fakta yang ada dapat kita lihat bahwa tingkat kesadaran masyarakat terhadap pemberian layanan pendidikan bagi anak sejak usia dini masih sangat rendah. Ini disebabkan karena kurangnya sosialisasi pemerintah akan pentingnya pendidikan sejak usia dini kepada masyarakat. Hal ini terbukti dengan masih adanya anak yang tidak mengenyam Pendidikan Anak Usia Dini (PAUD) dikarenakan anggapan masyarakat yang mengatakan bahwa pendidikan yang tepat diberikan kepada anak adalah pada saat usia 5-7 tahun. Selain sosialisasi pemerintah, keterbatasan jumlah tenaga pendidik dan

\footnotetext{
${ }^{6}$ Suyadi, Maulidya Ulfah, Konsep Dasar PAUD. (cet. 3; Bandung: PT.Remaja Rosda
} Karya, 2015), 18. 
172 | MUSAWA, Vol. 11 No. 2 Desember 2019 : 165 - 201

kependidikan serta faktor ekonomi juga menjadi penyebab yang dapat mempengaruhi mengapa orang tua tidak ingin terlalu cepat memasukan anak mereka kesekolah tanpa memahami apa sebenarnya tujuan Pendidikan Anak Usia Dini.

Secara umum, tujuan pendidikan anak usia dini adalah mengembangkan berbagai potensi anak sejak dini sebagai persiapan untuk hidup dan dapat menyesuaikan diri dengan lingkungannya. ${ }^{7}$

Dengan demikian, urgensi pendidikan Anak Usia Dini adalah untuk mengembangkan semua aspek perkembangan anak, meliputi perkembangan kognitif, bahasa, fisik motorik (motorik kasar, halus), sosial dan emosional.

\section{METODE PENELITIAN}

Dalam penelitian ini, jenis penelitian yang di gunakan adalah penelitian deskriptif. Peneliti mengamati dan melakukan kajian terhadap anak khususnya terhadap motorik kasar mereka melalui permainan lompat tali. Subjek penelitian adalah anak di RA DWP IAIN Palu yang berjumlah dari 20 anak terdiri 10 anak laki-laki dan 10 anak perempuan.

Teknik pengumpulan data yang digunakan adalah teknik observasi dan teknik dokumentasi. Adapun instrumen yang digunakan dalam penelitian ini adalah, kamera, tali yang tersebut dari rantaian karet gelang, lembar pengamatan dan rubrik penilaian anak yang berisikan 3 aspek yaitu keseimbangan melompat, dan kelincahan tubuh, dengan menggunakan 4 kategori yaitu:

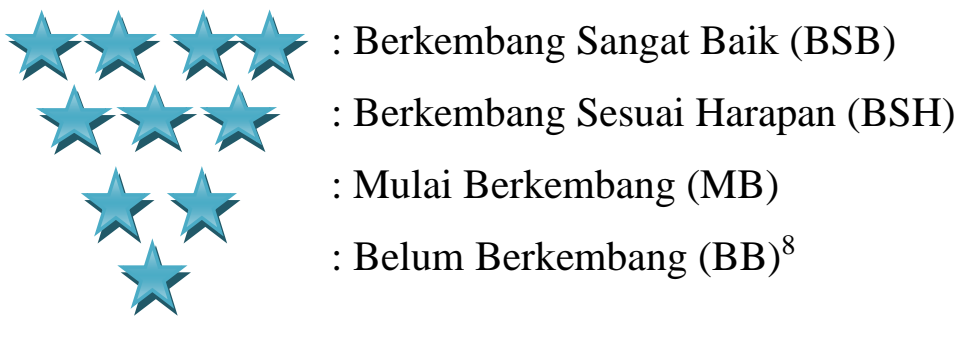
2016), 78.

${ }^{7}$ Novan Ardi Wiyani, Barnawi, Format PAUD. (cet.2; Jogjakarta: AR-Ruzz Media,

${ }^{8}$ Johni dimyati, metodologi penelitian pendidikan dan aplikasinya pada pendidikan anak usia dini (PAUD). (cet. 2; Jakarta: Kencana, 2014), 96. 
Setelah data terkumpul, selanjutnya data akan diolah dengan menggunakan teknik persentase, hasil olahan tersebut kemudian dianalisis secara deskriptif untuk mengetahui persentasi keberhasilan tindakan.

\section{HASIL PENELITIAN}

\section{Bentuk Metode Pembelajaran Motorik Kasar pada Anak Usia Dini}

Pada bagian ini, peneliti akan memaparkan hasil penelitian tindakan kelas yang dilakukan oleh peneliti di Raudhatul Athfal Dharma Wanita Persatuan IAIN Palu untuk penerapan Metode Pembelajaran motorik kasar pada anak usia dini khususnya Motorik Kasar dengan menggunakan permainan kadende dan permainan simpai sehingga peneliti dapat menguraikan di bawah ini, tentang hasil penelitian yang di dapatkan dari pra tindakan, siklus I dan siklus II sebagai berikut.

\section{Pra Tindakan}

Langkah awal dari penelitian ini, peneliti menyampaikan maksud dan tujuan peneliti kepada kepala Raudhatul Athfal Dharma Wanita Persatuan IAIN Palu, tentang rencana penelitian yang akan dilakukan di sekolah tersebut, serta memohon kesediaan salah seorang guru untuk menjadi pengamat dalam penelitian ini. Penelitian yang bersifat tindakan kelas ini diawali dengan melakukan observasi awal di lapangan, dengan tujuan melihat kemampuan anak dan kondisi kelas serta pembelajaran sebelum dilakukan penelitian.

Penelitian dilakukan secara bersiklus yaitu siklus I dan siklus II. Dengan menggunakan permainan kadende dan permainan simpai dengan meningkatankan kemampuan motorik kasar anak sehingga kemampuan motorik anak dapat berkembang sesuai harapan. Namun sebelum peniliti melakukan tindakan penelitian, terlebih dahulu peneliti melakukan observasi awal untuk melihat sampai dimana kemampuan perkembangan motorik anak. Kegiatan pra tindakan umumnya dilakukan sebelum peneliti memulai penelitian terhadap permainan permainan kadende. 
174 | MUSAWA, Vol. 11 No. 2 Desember 2019 : 165 - 201

\section{a. Permainan Kadende}

Pada saat permainan kadende di laksanakan, anak yang hadir berjumlah 20 anak. Adapun gerakan yang dilakukan dalam permainan ini yaitu berdiri dengan satu kaki, melompat, dan berlari. Dari hasil pengamatan, sangat terlihat jelas bahwa anak masih merasa kesulitan dalam melakukan ketiga gerakan tersebut. Adapun hasilnya dapat dipaparkan, sebagai berikut:

Tabel 1.

Kemampuan motorik kasar pada aspek keseimbangan (berdiri dengan satu kaki)

\begin{tabular}{|c|c|c|}
\hline Kategori & Frekuensi & \% \\
\hline Berkembang Sangat Baik & 4 & 20 \\
\hline Berkembang Sesuai Harapan & 5 & 25 \\
\hline Mulai Berkembang & 6 & 30 \\
\hline Belum Berkembang & 5 & 25 \\
\hline Jumlah & 20 & 100 \\
\hline
\end{tabular}

Dari tabel di atas, diketahui dari 20 anak yang menjadi subjek penelitian, untuk kemampuan motorik kasar pada aspek berdiri dengan satu kaki, terdapat 4 anak (20\%) dalam kategori Berkembang Sangat Baik (BSB) karena anak dapat berdiri satu kaki selama 30 detik, 5 anak (25\%) dalam kategori Berkembang Sesuai Harapan (BSH) karena anak dapat berdiri satu kaki selama 20 detik, 6 anak (30\%) dalam kategori Mulai Berkembang (MB) karena anak dapat berdiri satu kaki dengan bantuan guru, dan 5 anak (25\%) dalam kategori Belum Berkembang (BB) karena anak belum dapat berdiri dengan satu kaki.

Tabel 2

Kemampuan Motorik Kasar pada aspek Melompat

\begin{tabular}{|c|c|c|}
\hline Kategori & Frekuensi & $\mathbf{\%}$ \\
\hline Berkembang Sangat Baik & 5 & 25 \\
\hline Berkembang Sesuai Harapan & 5 & 25 \\
\hline Mulai Berkembang & 6 & 30 \\
\hline Belum Berkembang & 4 & 20 \\
\hline Jumlah & 20 & 100 \\
\hline
\end{tabular}


Dari tabel diatas, diketahui dari 20 anak yang menjadi subjek penelitian, kemampuan motorik kasar pada aspek melompat, terdapat 5 anak (25\%) dalam kategori Berkembang Sangat Baik BSB) karena anak dapat melompat dari kejauhan 20-30 cm, 5 anak (25\%) dalam kategori Berkembang Sesuai Harapan (BSH) karena anak dapat melompat dari kejauhan 10-20 cm, 6 anak (30\%) dalam kategori Mulai Berkembang (MB) karena anak dapat melompat dari kejauhan $5 \mathrm{~cm}$, dan 4 anak (20\%) dalam kategori Belum Berkembang (BB) karena anak belum dapat melompat dari kejauhan.

Tabel 3

Kemampuan Motorik Kasar pada aspek Berlari (kelincahan)

\begin{tabular}{|c|c|c|}
\hline Kategori & Frekuensi & \% \\
\hline Berkembang Sangat Baik & 10 & 50 \\
\hline Berkembang Sesuai Harapan & 4 & 20 \\
\hline Mulai Berkembang & 6 & 30 \\
\hline Belum Berkembang & 0 & 0 \\
\hline Jumlah & 20 & 100 \\
\hline
\end{tabular}

Dari tabel diatas, diketahui dari 20 anak yang menjadi subjek penelitian, untuk kemampuan motorik kasar anak pada aspek berlari, terdapat 10 anak (50\%) dalam kategori Berkembang Sangat Baik (BSB) karena anak dapat berlari dengan cepat tanpa terjatuh selama 30 detik, 4 anak (20\%) dalam kategori Berkembang Sesuai Harapan (BSH) karena anak dapat berlari dengan cepat tanpa terjatuh selama 20 detik, 6 anak (30\%) dalam kategori Mulai Berkembang (MB) karena anak dapat berlari dengan cepat tanpa terjatuh selama 10 detik, dan 0 anak $(0 \%)$ dalam kategori Belum Berkembang (BB) karena anak belum dapat berlari dengan cepat. 
176 | MUSAWA, Vol. 11 No. 2 Desember 2019 : 165 - 201

Tabel 4

Rekapitulasi Hasil Pengamatan Pra Tindakan Bermain Kadende

\begin{tabular}{|c|c|c|c|c|c|c|c|c|}
\hline \multirow{3}{*}{ No } & \multirow{3}{*}{ Kategori } & \multicolumn{6}{|c|}{$\begin{array}{c}\text { Kemampuan Motorik Kasar yang } \\
\text { Diamati }\end{array}$} & \multirow{3}{*}{$\%$} \\
\hline & & \multicolumn{2}{|c|}{$\begin{array}{c}\text { Aspek berdiri } \\
\text { dengan satu } \\
\text { kaki }\end{array}$} & \multicolumn{2}{|c|}{$\begin{array}{c}\text { Aspek } \\
\text { Melompat }\end{array}$} & \multicolumn{2}{|c|}{$\begin{array}{l}\text { Aspek } \\
\text { Berlari }\end{array}$} & \\
\hline & & $\mathrm{F}$ & $\%$ & $\mathrm{~F}$ & $\%$ & $\mathrm{~F}$ & $\%$ & \\
\hline 1. & $\begin{array}{c}\text { Berkembang Sangat } \\
\text { Baik }\end{array}$ & 4 & 20 & 5 & 25 & 10 & 50 & 31,67 \\
\hline 2. & $\begin{array}{c}\text { Berkembang Sesuai } \\
\text { Harapan }\end{array}$ & 5 & 25 & 5 & 25 & 4 & 20 & 23,33 \\
\hline 3. & Mulai Berkembang & 6 & 30 & 6 & 30 & 6 & 30 & 30 \\
\hline 4. & Belum Berkembang & 5 & 25 & 4 & 20 & 0 & 0 & 15 \\
\hline & Jumlah & 20 & 100 & 20 & 100 & 20 & 100 & 100 \\
\hline
\end{tabular}

Berdasarkan tabel diatas, setelah dirata-ratakan ketiga aspek yang diamati, terdapat 31,67\% dalam kategori Berkembang Sangat Baik (BSB), 23,33\% dalam kategori Berkembang Sesuai Harapan (BSH), 30\% dalam kategori Mulai Berkembang (MB), dan 15\% dalam kategori Belum Berkembang (BB).

\section{Hasil Pengamatan Tindakan Siklus I}

Dibagian tindakan siklus I ini, peneliti melakukan proses belajar mengajar di luar kelas berdasarkan RPPH yang telah dibuat dalam meningkatkan kemampuan motorik kasar anak. Di dalam tindakan siklus I ini, peneliti melakukan dua kali tindakan atau 2 kali pertemuan. Agar setelah peneliti memulai tindakan kelas menggunakan permainan kadende dan permainan simpai, sehingga hasil yang di dapatkan lebih meningkat dibandingkan saat pra tindakan dilakukan.

\section{a. Permainan Kadende}

Permainan kadende ini dilakukan dengan dua kali pertemuan di kelas yang dimulai dengan membuat perencanaan, pelaksanaan, dan observasi. Saat penyajian materi, peneliti bertindak sebagai pengajar yang didampingi oleh rekan guru yang bertindak sebagai pengamat. 


\section{1) Perencanaan}

Perencanaan tindakan pada siklus I ini, sebagai berikut:

a) Menentukan tema dan tujuan pembelajaran.

b) Membuat Rencana Program Pembelajaran Harian (RPPH).

c) Menyediakan media pembelajaran.

d) Membuat lembar observasi aktivitas guru.

e) Membuat lembar penilaian peningkatan kemampuan motorik kasar anak.

f) Membuat rubrik penilaian peningkatan kemampuan motorik kasar anak.

2) Pelaksanaan

Melakukan proses pembelajaran di dalam kelas berdasarkan RPPH yang telah dibuat, yaitu melaksanakan kegiatan pembuka selama 30 menit yang dimulai dengan mengucapkan salam, dan membaca doa belajar. Setelah selesai membaca doa belajar, anak-anak diperintahkan untuk membaca surah pendek yaitu surah an-nas dan melafalkan doa memakai pakaian.

Melaksanakan kegiatan inti selama 60 menit. Dalam kegiatan inti, ada tiga jenis kegiatan bermain sambil belajar yang di gunakan yaitu mengenal suara binatang, membuat gambar bentuk kadende dan simpai, dan menggunting dan menempel kertas bentuk kadende dan simpai. Sambil menunggu waktu istirahat peneliti kemudian mengajak anak untuk melakukan permainan kadende dan permainan simpai.

Setelah waktu istirahat selesai, anak-anak masuk kedalam kelas kemudian melaksanakan kegiatan penutup selama 30 menit dengan menunjukan hasil karyanya dengan bangga, kemudian melafalkan hadits tebar salam, dan melafalkan niat sholat subuh, setelah itu guru dan anak mendiskusikan kegiatan sehari selama pembelajaran berlansung dan terakhir membaca syair pulang sekolah, membaca doa dan salam.

3) Observasi

Melakukan observasi aktivitas kegiatan guru pada saat proses pembelajaran berlangsung yang diamati langsung oleh teman dan guru kelas yang bertindak sebagai pengamat. Adapun hasil pengamatan aktivitas anak pada tindakan siklus I dapat dilihat pada tabel di bawah ini: 
178 | MUSAWA, Vol. 11 No. 2 Desember 2019 : 165 - 201

Tabel 5

Kemampuan Motorik kasar dalam berdiri dengan satu kaki (keseimbangan)

\begin{tabular}{|c|c|c|}
\hline Kategori & Frekuensi & \% \\
\hline Berkembang Sangat Baik & 6 & 30 \\
\hline Berkembang Sesuai Harapan & 6 & 30 \\
\hline Mulai Berkembang & 6 & 30 \\
\hline Belum Berkembang & 2 & 10 \\
\hline Jumlah & 20 & 100 \\
\hline
\end{tabular}

Dari tabel diatas, diketahui dari 20 anak yang menjadi subjek penelitian, untuk kemampuan motorik kasar dalam berdiri dengan satu kaki, terdapat 6 anak (30\%) dalam kategori Berkembang Sangat Baik (BSB) karena anak dapat berdiri satu kaki selama 30 detik, 6 anak (30\%) dalam kategori Berkembang Sesuai Harapan (BSH) karena anak dapat berdiri satu kaki selama 20 detik, 6 anak (30\%) dalam kategori Mulai Berkembang (MB) karena anak dapat berdiri satu kaki dengan bantuan guru, dan 2 anak (10\%) dalam kategori Belum Berkembang (BB) karena anak belum dapat berdiri dengan satu kaki.

Tabel 6

Kemampuan Motorik kasar dalam Melompat

\begin{tabular}{|c|c|c|}
\hline Kategori & Frekuensi & \% \\
\hline Berkembang Sangat Baik & 8 & 40 \\
\hline Berkembang Sesuai Harapan & 5 & 25 \\
\hline Mulai Berkembang & 6 & 30 \\
\hline Belum Berkembang & 1 & 5 \\
\hline Jumlah & 20 & 100 \\
\hline
\end{tabular}

Dari tabel diatas, diketahui dari 20 anak yang menjadi subjek penelitian, kemampuan motorik kasar dalam aspek melompat, terdapat 8 anak (40\%) dalam kategori Berkembang Sangat Baik (BSB) karena anak dapat melompat dari kejauhan 20-30 cm, 5 anak (25\%) dalam kategori Berkembang Sesuai Harapan (BSH) karena anak dapat melompat dari kejauhan 10-20 cm, 6 anak (30\%) dalam kategori Mulai Berkembang (MB) karena anak dapat 
melompat dari kejauhan $5 \mathrm{~cm}$, dan 1 anak (5\%) dalam kategori Belum Berkembang (BB) karena anak belum dapat melompat dari kejauhan.

Tabel 7

Kemampuan Motorik Kasar dalam Aspek Berlari (kelincahan)

\begin{tabular}{|c|c|c|}
\hline Kategori & Frekuensi & \% \\
\hline Berkembang Sangat Baik & 18 & 90 \\
\hline Berkembang Sesuai Harapan & 2 & 10 \\
\hline Mulai Berkembang & 0 & 0 \\
\hline Belum Berkembang & 0 & 0 \\
\hline Jumlah & 20 & 100 \\
\hline
\end{tabular}

Dari tabel diatas, diketahui dari 20 anak yang menjadi subjek penelitian, untuk kemampuan motorik kasar dalam berlari, terdapat 18 anak (90\%) dalam kategori Berkembang Sangat Baik (BSB) karena anak dapat berlari dengan cepat tanpa terjatuh selama 30 detik, 2 anak (10\%) dalam kategori Berkembang Sesuai Harapan (BSH) karena anak dapat berlari dengan cepat tanpa terjatuh selama 20 detik, 0 anak (0\%) dalam kategori Mulai Berkembang (MB) karena anak dapat berlari dengan cepat tanpa terjatuh selama 10 detik, dan 0 anak (0\%) dalam kategori Belum Berkembang (BB) karena anak sudah dapat berlari dengan cepat.

Setelah melihat seluruh hasil yang diperoleh dari bermain kadende, maka dapat diakumulasikan secara keseluruhan data yang diperoleh dari bermain kadende adalah sebagai berikut:

Tabel 8

Rekapitulasi Hasil Pengamatan Tindakan Siklus I Permainan Kadende

\begin{tabular}{|c|c|c|c|c|c|c|c|c|}
\hline \multirow{2}{*}{ No } & \multirow{2}{*}{ Kategori } & \multicolumn{3}{|c|}{ Kemampuan Motorik kasar yang Diamati } & \multirow{2}{*}{\begin{tabular}{c}
\multirow{2}{*}{ Berdiri } \\
dengan satu \\
kaki
\end{tabular}} & \multicolumn{2}{|c|}{ Melompat } & \multicolumn{2}{|c|}{ Berlari } & \multirow{2}{*}{$\%$} \\
\cline { 3 - 8 } & & $\mathrm{F}$ & $\%$ & $\mathrm{~F}$ & $\%$ & $\mathrm{~F}$ & $\%$ & \\
\hline 1. & $\begin{array}{c}\text { Berkembang } \\
\text { Sangat Baik }\end{array}$ & 6 & 30 & 8 & 40 & 18 & 90 & 53,33 \\
\hline 2. & $\begin{array}{c}\text { Berkembang } \\
\text { Sesuai Harapan }\end{array}$ & 6 & 30 & 5 & 25 & 2 & 10 & 21,67 \\
\hline 3. & $\begin{array}{c}\text { Mulai } \\
\text { Berkembang }\end{array}$ & 6 & 30 & 6 & 30 & 0 & 0 & 20 \\
\hline
\end{tabular}


180 | MUSAWA, Vol. 11 No. 2 Desember 2019 : 165 - 201

\begin{tabular}{|c|c|c|c|c|c|c|c|c|}
\hline 4. & $\begin{array}{c}\text { Belum } \\
\text { Berkembang }\end{array}$ & 2 & 10 & 1 & 5 & 0 & 0 & 5 \\
\hline Jumlah & 20 & 100 & 20 & 100 & 100 & 100 & 100 \\
\hline
\end{tabular}

Berdasarkan tabel diatas setelah dirata-ratakan ketiga aspek yang diamati, terdapat 53,33\% dalam kategori Berkembang Sangat Baik (BSB), 21,67\% dalam kategori Berkembang Sesuai Harapan (BSH), 20\% dalam kategori Mulai Berkembang (MB), dan 5\% dalam kategori Belum Berkembang (BB).

Setelah melihat persentase yang diperoleh dari hasil pengamatan tindakan siklus I permainan kadende, jelas terlihat bahwa persentase yang diperoleh dari 3 aspek pengamatan peningkatan kemampuan motorik kasar anak yang dinilai dalam berdiri dengan satu kaki, melompat, dan berlari telah mencapai persentase keberhasilan yang diharapkan peneliti. Namun peneliti ingin meningkatkan kembali hasil presentase agar dapat menjadi perbandingan. Berdasarkan hal tersebut, peneliti melakukan perbaikan tindakan pada siklus II.

4) Refleksi Tindakan Siklus I

Berdasarkan hasil pengamatan yang dilakukan pada aktivitas guru yang masuk dalam kategori cukup yang harus ditingkatkan untuk mencapai kriteria keberhasilan baik. Sedangkan, aktivitas anak sekalipun sudah terdapat peningkatan dari hasil pengamatan pra tindakan, hasil tindakan siklus I sudah mencapai persentase keberhasilan tindakan. Namun hasil yang diharapkan belum sesuai dengan tujuan penelitian, yaitu untuk meningkatkan kemampuan motorik kasar anak. Hal ini disebabkan karena masih ada beberapa anak yang masuk dalam kategori Belum Berkembang dalam ketiga aspek pengamatan anak dalam berdiri dengan satu kaki, melompat, dan berlari. Selain itu, ada temuan-temuan atau kejadian-kejadian yang didapatkan selama tindakan berlangsung yang menjadi kelemahan dan perlu diperbaiki pada perencanaan tindakan selanjutnya di Raudhatul Athfal Dharma Wanita Persatuan IAIN Palu. 
Tabel 9

Refleksi Tindakan Siklus I Bermain Kadende

\begin{tabular}{|c|l|l|l|}
\hline No & \multicolumn{1}{|c|}{ Kelemahan } & \multicolumn{1}{c|}{$\begin{array}{c}\text { Analisis } \\
\text { Penyebab }\end{array}$} & \multicolumn{1}{c|}{ Rekomendasi } \\
\hline 1 & $\begin{array}{l}\text { Kemampuan anak } \\
\text { dalam berdiri dengan } \\
\text { satu kaki, melompat, } \\
\text { dan berlari belum } \\
\text { berkembang dengan } \\
\text { baik }\end{array}$ & $\begin{array}{l}\text { Kurangnya latihan } \\
\text { dan metode } \\
\text { bermain yang } \\
\text { digunakan dalam } \\
\text { pembelajaran anak }\end{array}$ & $\begin{array}{l}\text { Guru/peneliti } \\
\text { meningkatkan latihan } \\
\text { danmetode bermain } \\
\text { kepada anak sehingga } \\
\text { motorik kasar anak dapat } \\
\text { dikembangkan }\end{array}$ \\
\hline 2 & $\begin{array}{l}\text { Partisipasi anak dalam } \\
\text { pembelajaran masih } \\
\text { kurang }\end{array}$ & $\begin{array}{l}\text { Anak masih } \\
\text { cenderung senang } \\
\text { bermain dengan } \\
\text { teman di } \\
\text { sebelahnya }\end{array}$ & $\begin{array}{l}\text { Guru/peneliti memberikan } \\
\text { motivasi kepada anak agar } \\
\text { dapat memperhatikan cara } \\
\text { bermain kadende dalam } \\
\text { hal ini berdiri dengan satu } \\
\text { kaki, melompat, dan } \\
\text { berlari dengan baik }\end{array}$ \\
\hline
\end{tabular}

\section{Hasil Pengamatan Tindakan Siklus II}

Dibagian tindakan siklus II ini, peneliti melakukan proses belajar mengajar di luar kelas berdasarkan RPPH yang telah dibuat dalam meningkatkan kemampuan motorik kasar anak. Di dalam tindakan siklus II ini, peneliti melakukan dua kali tindakan atau 2 kali pertemuan. Agar setelah peneliti memulai tindakan kelas menggunakan permainan kadende, sehingga hasil yang di dapatkan lebih meningkat dibandingkan saat tindakan siklus I dilakukan.

\section{a. Permainan Kadende}

Permainan kadende ini dilakukan dengan dua kali pertemuan di kelas yang dimulai dengan membuat perencanaan, pelaksanaan, dan observasi. Saat penyajian materi, peneliti bertindak sebagai pengajar yang didampingi oleh rekan guru yang bertindak sebagai pengamat.

1) Perencanaan

Perencanaan tindakan pada siklus II ini adalah sebagai berikut:

a) Menentukan tema dan tujuan pembelajaran. 
182 | MUSAWA, Vol. 11 No. 2 Desember 2019 : 165 - 201

b) Membuat Rencana Program Pembelajaran Harian (RPPH)

c) Menyediakan media pembelajaran.

d) Membuat lembar observasi aktivitas guru.

e) Membuat lembar penilaian peningkatan kemampuan motoric kasar anak.

f) Membuat rubrik penilaian peningkatan kemampuan motorik kasar anak.

2) Pelaksanaan

Melakukan proses pembelajaran di dalam kelas berdasarkan RPPH yang telah dibuat, yaitu melaksanakan kegiatan pembuka selama 30 menit yang dimulai dengan mengucapkan salam, dan membaca doa belajar. Setelah selesai membaca doa belajar, anak-anak diperintahkan untuk membaca surah pendek yaitu surah an-nas dan melafalkan doa memakai pakaian.

Melaksanakan kegiatan inti selama kurang lebih 60 menit. Dalam kegiatan inti ini, ada tiga jenis kegiatan bermain yang digunakan yaitu menyusun puzzle, kemudian memasangkan binatang dengan makanannya, dan terakhir melipat kertas bentuk amplop.

Setelah waktu istirahat selesai, anak-anak masuk kedalam kelas kemudian melaksanakan kegiatan penutup selama 30 menit dengan menunjukan hasil karyanya dengan bangga, kemudian melafalkan hadits tebar salam, dan melafalkan niat sholat subuh, setelah itu guru dan anak mendiskusikan kegiatan sehari selama pembelajaran berlansung dan terakhir membaca syair pulang sekolah, membaca doa dan salam.

3) Observasi

Melakukan observasi aktivitas kegiatan guru pada saat proses pembelajaran berlangsung yang diamati langsung oleh teman yang bertindak sebagai pengamat. Adapun hasil pengamatan aktivitas anak pada tindakan siklus II dapat dilihat dari tabel di bawah ini:

Tabel 10

Kemampuan Motorik kasar dalam berdiri dengan satu kaki

\begin{tabular}{|c|c|c|}
\hline Kategori & Frekuensi & \% \\
\hline Berkembang Sangat Baik & 9 & 45 \\
\hline Berkembang Sesuai Harapan & 6 & 30 \\
\hline Mulai Berkembang & 3 & 15 \\
\hline Belum Berkembang & 2 & 10 \\
\hline
\end{tabular}




\begin{tabular}{|c|c|c|}
\hline Jumlah & 20 & 100 \\
\hline
\end{tabular}

Dari tabel diatas, diketahui dari 20 anak yang menjadi subjek penelitian, untuk kemampuan motorik kasar dalam berdiri dengan satu kaki, terdapat 9 anak (45\%) dalam kategori Berkembang Sangat Baik (BSB) karena anak dapat berdiri satu kaki selama 30 detik, 6 anak (30\%) dalam kategori Berkembang Sesuai Harapan (BSH) karena anak dapat berdiri satu kaki selama 20 detik, 3 anak (15\%) dalam kategori Mulai Berkembang (MB) karena anak dapat berdiri satu kaki selama 10 detik, dan 2 anak (10\%) dalam kategori Belum Berkembang (BB) karena anak belum dapat berdiri dengan satu kaki.

Tabel 11

Kemampuan Motorik kasar dalam Melompat

\begin{tabular}{|c|c|c|}
\hline Kategori & Frekuensi & \% \\
\hline Berkembang Sangat Baik & 9 & 45 \\
\hline Berkembang Sesuai Harapan & 6 & 30 \\
\hline Mulai Berkembang & 4 & 20 \\
\hline Belum Berkembang & 1 & 5 \\
\hline Jumlah & 20 & 100 \\
\hline
\end{tabular}

Dari tabel diatas diketahui dari 20 anak yang menjadi subjek penelitian, kemampuan motorik kasar dalam melompat, terdapat 9 anak (45\%) dalam kategori Berkembang Sangat Baik (BSB) karena anak dapat melompat dari kejauhan 20-30 cm, 6 anak (30\%) dalam kategori Berkembang Sesuai Harapan (BSH) karena anak dapat melompat dari kejauhan 10-20 cm, 4 anak (20\%) dalam kategori Mulai Berkembang (MB) karena anak dapat melompat dari kejauhan $5 \mathrm{~cm}$, dan 1 anak (5\%) dalam kategori Belum Berkembang (BB) karena anak belum dapat melompat dari kejauhan.

Tabel 12

Kemampuan Motorik Kasar dalam Berlari

\begin{tabular}{|c|c|c|}
\hline Kategori & Frekuensi & \% \\
\hline Berkembang Sangat Baik & 18 & 90 \\
\hline
\end{tabular}


184 | MUSAWA, Vol. 11 No. 2 Desember 2019 : 165 - 201

\begin{tabular}{|c|c|c|}
\hline Berkembang Sesuai Harapan & 2 & 10 \\
\hline Mulai Berkembang & 0 & 0 \\
\hline Belum Berkembang & 0 & 0 \\
\hline Jumlah & 20 & 100 \\
\hline
\end{tabular}

Dari tabel diatas, diketahui dari 20 anak yang menjadi subjek penelitian, untuk kemampuan motorik Kasar dalam Berlari, terdapat 18 anak (90\%) dalam kategori Berkembang Sangat Baik (BSB) karena anak dapat berlari dengan cepat tanpa terjatuh selama 30 detik, 2 anak (10\%) dalam kategori Berkembang Sesuai Harapan (BSH) karena anak dapat berlari dengan cepat tanpa terjatuh selama 20 detik, 0 anak (0\%) dalam kategori Mulai Berkembang (MB) karena anak dapat berlari dengan cepat tanpa terjatuh selama 10 detik, dan 0 anak (0\%) dalam kategori Belum Berkembang (BB) karena anak belum dapat berlari dengan cepat.

Setelah melihat seluruh hasil yang diperoleh dari bermain kadende, maka dapat diakumulasikan secara keseluruhan data yang diperoleh dari bermain kadende adalah sebagai berikut:

Tabel 13

Rekapitulasi Hasil Pengamatan Tindakan Siklus II Permainan Kadende

\begin{tabular}{|c|c|c|c|c|c|c|c|c|}
\hline \multirow{3}{*}{ No } & \multirow{3}{*}{ Kategori } & \multicolumn{6}{|c|}{$\begin{array}{c}\text { Kemampuan Motorik kasar yang } \\
\text { Diamati }\end{array}$} & \multirow{3}{*}{$\%$} \\
\hline & & \multicolumn{2}{|c|}{$\begin{array}{l}\text { berdiri dengan } \\
\text { satu kaki }\end{array}$} & \multicolumn{2}{|c|}{ Melompat } & \multicolumn{2}{|c|}{ Berlari } & \\
\hline & & $\mathrm{F}$ & $\%$ & $\mathrm{~F}$ & $\%$ & $\mathrm{~F}$ & $\%$ & \\
\hline 1. & $\begin{array}{l}\text { Berkembang Sangat } \\
\text { Baik }\end{array}$ & 9 & 45 & 9 & 45 & 18 & 90 & 60 \\
\hline 2. & $\begin{array}{l}\text { Berkembang Sesuai } \\
\text { Harapan }\end{array}$ & 6 & 30 & 6 & 30 & 2 & 10 & 23,33 \\
\hline 3. & Mulai Berkembang & 3 & 15 & 4 & 20 & 0 & 0 & 11,67 \\
\hline 4. & Belum Berkembang & 2 & 10 & 1 & 5 & 0 & 0 & 5 \\
\hline & Jumlah & 20 & 100 & 20 & 100 & 20 & 100 & 100 \\
\hline
\end{tabular}

Berdasarkan tabel diatas, setelah dirata-ratakan ketiga aspek yang diamati, terdapat 60\% dalam kategori Berkembang Sangat Baik (BSB), 23,33\% 
dalam kategori Berkembang Sesuai Harapan (BSH), 11,67\% dalam kategori Mulai Berkembang (MB), dan 5\% dalam kategori Belum Berkembang (BB).

Setelah melihat persentase yang diperoleh dari hasil pengamatan tindakan siklus II, jelas terlihat bahwa persentase yang diperoleh dari 3 aspek pengamatan peningkatan kemampuan motorik kasar anak yang dinilai dalam berdiri dengan satu kaki, melompat, dan berlari telah mencapai keberhasilan tindakan yang diharapkan peneliti. Oleh karena itu, tidak perlu dilakukan perbaikan pada tindakan selanjutnya.

4) Refleksi Tindakan Siklus II

Dari hasil pengamatan yang dilakukan pada aktivitas kegiatan guru semua aspek yang diamati telah masuk dalam kategori baik. Sedangkan, aktivitas anak dalam proses pembelajaran telah mencapai persentase keberhasilan tindakan untuk ketiga aspek pengamatan anak dalam berdiri dengan satu kaki, melompat, dan berlari Dapat disimpulkan bahwa melalui bermain kadende dan bermain simpai yang telah diterapkan oleh guru dalam proses pembelajaran telah meningkatkan kemampuan motorik kasar anak di Raudhatul Athfal Dharma Wanita Persatuan IAIN PALU.

Tabel 14

\section{Refleksi Tindakan Siklus II}

\begin{tabular}{|l|l|l|}
\hline No & \multicolumn{1}{|c|}{ Temuan } & \multicolumn{1}{|c|}{ Analisis Penyebab } \\
\hline 1 & $\begin{array}{l}\text { Anak sudah dapat berdiri } \\
\text { dengan satu, melompat, dan } \\
\text { berlari dengan baik }\end{array}$ & $\begin{array}{l}\text { Guru/peneliti sangat rutin melatih dan } \\
\text { membimbing anak dalam kegiatan } \\
\text { bermain kadende dan bermain simpai }\end{array}$ \\
\hline 2 & $\begin{array}{l}\text { Anak sudah menunjukkan } \\
\text { kemauan dalam mengerjakan } \\
\text { tugas yang diberikan guru }\end{array}$ & $\begin{array}{l}\text { Permainan yang diberikan sesuai } \\
\text { dengan keinginan anak }\end{array}$ \\
\hline
\end{tabular}


186 | MUSAWA, Vol. 11 No. 2 Desember 2019 : 165 - 201

\begin{tabular}{|l|lr|lrr|}
\hline 3 & Sudah & tidak ada lagi anak & Anak sudah senang dalam kegiatan \\
yang & cenderung & senang & bermain kadende dan bermain simpai, \\
bermain dalam kelas dengan & mereka sangat antusias ketika melihat \\
teman r duduknya, dan & berbagai macam kadende dan simpai \\
perhatian anak sudah & yang disediakan guru \\
terfokus pada penjelasan guru & \\
dalam permainan kadende dan & \\
permainan simpai &
\end{tabular}

\section{b. Bahasan Hasil Penelitian}

Berdasarkan observasi yang telah peneliti lakukan mulai dari sebelum tindakan dilakukan sampai siklus I dan siklus II dapat dibahas, sebagai berikut:

\section{Bahasan Pra Tindakan}

\section{a. Permainan Kadende}

Berdasarkan hasil penelitian pada pra tindakan, diketahui dari 20 anak yang menjadi subjek penelitian, untuk kemampuan motorik kasar pada aspek berdiri dengan satu kaki, terdapat 4 anak (20\%) dalam kategori Berkembang Sangat Baik (BSB) karena anak dapat berdiri satu kaki selama 30 detik, 5 anak (25\%) dalam kategori Berkembang Sesuai Harapan (BSH) karena anak dapat berdiri satu kaki selama 20 detik, 6 anak (30\%) dalam kategori Mulai Berkembang (MB) karena anak dapat berdiri satu kaki dengan bantuan guru, dan 5 anak (25\%) dalam kategori Belum Berkembang (BB) karena anak belum dapat berdiri dengan satu kaki.

Kemampuan motorik kasar dalam melompat, terdapat terdapat 5 anak (25\%) dalam kategori Berkembang Sangat Baik (BSB) karena anak dapat melompat dari kejauhan 20-30 cm, 5 anak (25\%) dalam kategori Berkembang Sesuai Harapan (BSH) karena anak dapat melompat dari kejauhan 10-20 cm, 6 anak (30\%) dalam kategori Mulai Berkembang (MB) karena anak dapat melompat dari kejauhan $5 \mathrm{~cm}$, dan 4 anak (20\%) dalam kategori Belum Berkembang (BB) karena anak belum dapat melompat dari kejauhan. 
Kemampuan motorik kasar dalam berlari, terdapat 10 anak (50\%) dalam kategori Berkembang Sangat Baik (BSB) karena anak dapat berlari dengan cepat tanpa terjatuh selama 30 detik, 4 anak (20\%) dalam kategori Berkembang Sesuai Harapan (BSH) karena anak dapat berlari dengan cepat tanpa terjatuh selama 20 detik, 6 anak (30\%) dalam kategori Mulai Berkembang (MB) karena anak dapat berlari dengan cepat tanpa terjatuh selama 10 detik, dan 0 anak (0\%) dalam kategori Belum Berkembang (BB) karena anak belum dapat berlari dengan cepat.

\section{Bahasan Tindakan Siklus I}

\section{a. Bermain Kadende}

Berdasarkan hasil penelitian pada Siklus I, diketahui dari 20 anak yang menjadi subjek penelitian, untuk kemampuan motorik kasar pada aspek berdiri dengan satu kaki terdapat 6 anak (30\%) dalam kategori Berkembang Sangat Baik (BSB) karena anak dapat berdiri satu kaki selama 30 detik, 6 anak (30\%) dalam kategori Berkembang Sesuai Harapan (BSH) karena anak dapat berdiri satu kaki selama 20 detik, 6 anak (30\%) dalam kategori Mulai Berkembang (MB) karena anak dapat berdiri satu kaki dengan bantuan guru, dan 2 anak (10\%) dalam kategori Belum Berkembang (BB) karena anak belum dapat berdiri dengan satu kaki. .

Kemampuan motorik kasar dalam aspek melompat, terdapat 8 anak (40\%) dalam kategori Berkembang Sangat Baik (BSB) karena anak dapat melompat dari kejauhan 20-30 cm, 5 anak (25\%) dalam kategori Berkembang Sesuai Harapan (BSH) karena anak dapat melompat dari kejauhan 10-20 cm, 6 anak (30\%) dalam kategori Mulai Berkembang (MB) karena anak dapat melompat dari kejauhan $5 \mathrm{~cm}$, dan 1 anak (5\%) dalam kategori Belum Berkembang (BB) karena anak belum dapat melompat dari kejauhan.

Kemampuan motorik Kasar dalam Berlari, terdapat 18 anak (90\%) dalam kategori Berkembang Sangat Baik (BSB) karena anak dapat berlari dengan cepat tanpa terjatuh selama 30 detik, 2 anak (10\%) dalam kategori Berkembang Sesuai Harapan (BSH) karena anak dapat berlari dengan cepat 
188 | MUSAWA, Vol. 11 No. 2 Desember 2019 : 165 - 201

tanpa terjatuh selama 20 detik, 0 anak (0\%) dalam kategori Mulai Berkembang (MB) karena anak dapat berlari dengan cepat tanpa terjatuh selama 10 detik, dan 0 anak (0\%) dalam kategori Belum Berkembang (BB) karena anak belum dapat berlari dengan cepat.

\section{Bahasan Tindakan Siklus II}

a. Bermain Kadende

Berdasarkan hasil penelitian pada Siklus II, diketahui dari 20 anak yang menjadi subjek penelitian, untuk kemampuan motorik kasar pada berdiri dengan satu kaki, terdapat 9 anak (45\%) dalam kategori Berkembang Sangat Baik (BSB) karena anak dapat berdiri satu kaki selama 30 detik, 6 anak (30\%) dalam kategori Berkembang Sesuai Harapan (BSH) karena anak dapat berdiri satu kaki selama 20 detik, 3 anak (15\%) dalam kategori Mulai Berkembang (MB) karena anak dapat berdiri satu kaki selama 10 detik, dan 2 anak (10\%) dalam kategori Belum Berkembang (BB) karena anak belum dapat berdiri dengan satu kaki.

Kemampuan motorik kasar pada aspek melompat, terdapat terdapat 9 anak (45\%) dalam kategori Berkembang Sangat Baik (BSB) karena anak dapat melompat dari kejauhan 20-30 cm, 6 anak (30\%) dalam kategori Berkembang Sesuai Harapan (BSH) karena anak dapat melompat dari kejauhan 10-20 cm, 4 anak (20\%) dalam kategori Mulai Berkembang (MB) karena anak dapat melompat dari kejauhan $5 \mathrm{~cm}$, dan 1 anak (5\%) dalam kategori Belum Berkembang (BB) karena anak belum dapat melompat dari kejauhan. .

Kemampuan motorik kasar anak pada aspek berlari, terdapat terdapat 18 anak (90\%) dalam kategori Berkembang Sangat Baik (BSB) karena anak dapat berlari dengan cepat tanpa terjatuh selama 30 detik, 2 anak (10\%) dalam kategori Berkembang Sesuai Harapan (BSH) karena anak dapat berlari dengan cepat tanpa terjatuh selama 20 detik, 0 anak (0\%) dalam kategori Mulai Berkembang (MB) karena anak dapat berlari dengan cepat tanpa terjatuh selama 10 detik, dan 0 anak (0\%) dalam kategori Belum Berkembang (BB) karena anak belum dapat berlari dengan cepat. 


\section{B. PENERAPAN METODE PEMBELAJARAN MOTORIK PADA ANAK USIA DINI.}

Pelaksanaan penelitian tindakan kelas untuk meningkatkan motorik kasar anak melalui metode pembelajaran motorik. Proses pembelajaran ini dilaksanakan sebanyak dua siklus tiap siklus dua kali tindakan pembelajaran, dimulai dari kegiatan awal, kegiatan inti, kegiatan penutup dengan empat katagori penilaian, yaitu Berkembang Sangat Baik (BSB), Berkembang Sesuai Harapan (BSH), Mulai Berkembang (MB), dan Belum Berkembang (BB) dengan tiga aspek yang diamati, yakni kleseimbangan, kekuatan tubuh anak dan kelincahan tubuh. Untuk memberikan gambaran hasil penelitian ini, maka peneliti mengikuti langkahlangkah, sebagai berikut :

\section{Pengamatan Pra Tindakan}

Kegiatan pra tindakan dilakukan sebelum melaksanakan penelitian dalam bentuk proses pembelajaran di RA DWP IAIN Palu, dengan maksud untuk mengetahui peningkatan motorik kasar anak. Kemampuan anak dapat dilihat pada tabel berikut :

Tabel 1. Aspek keseimbangan

\begin{tabular}{|c|c|c|}
\hline Katagori & Frekuensi ( f ) & Persentase (\%) \\
\hline Berkembang Sangat Baik & 1 & 5 \\
\hline Berkembang Sesuai Harapan & 2 & 5 \\
\hline Mulai Berkembang & 1 & 30 \\
\hline Belum Berkembang & 16 & 100 \\
\hline Jumlah & 20 & 10 \\
\hline
\end{tabular}

Berdasarkan tabel 1, terdapat 2 anak (10\%) dalam katagori Berkembang Sangat Baik, 2 anak (10\%) dalam katagori Berkembang Sesuai Harapan, katagori Mulai Berkembang 1 anak (5\%), dan 16 anak (30\%) dalam katagori Belum Berkembang, pada penilaian keseimbangan tubuh anak. 
190 | MUSAWA, Vol. 11 No. 2 Desember 2019 : 165 - 201

Tabel 2. Aspek kekuatan tubuh anak

\begin{tabular}{|c|c|c|}
\hline Katagori & Frekuensi (f) & Persentase (\%) \\
\hline Berkembang Sangat Baik & 1 & 5 \\
\hline Berkembang Sesuai Harapan & 3 & 20 \\
\hline Mulai Berkembang & 4 & 60 \\
\hline Belum Berkembang & 12 & 100 \\
\hline Jumlah & 20 & \\
\hline
\end{tabular}

Data yang disajikan tabe1 2, terdapat 1 anak (5\%) katagori Berkembang Sangat Baik, 3 anak (15\%) katagori Berkembang Sesuai Harapan, Mulai Berkembang 4 anak (20\%), dan 12 anak (60\%) Belum Berkembang pada aspek kekuatan tubuh pada anak.

Tabel 3 Aspek kelincahan tubuh

\begin{tabular}{|c|c|c|}
\hline Katagori & Frekuensi ( f ) & Persentase (\%) \\
\hline Berkembang Sangat Baik & 2 & 10 \\
\hline Berkembang Sesuai Harapan & 3 & 25 \\
\hline Mulai Berkembang & 5 & 50 \\
\hline Belum Berkembang & 10 & 100 \\
\hline Jumlah & 20 & 25 \\
\hline
\end{tabular}

Gambaran data pada tabel 3, terdapat 2 anak (10\%) katagori Berkembang Sangat Baik, 3 anak (15\%) Berkembang Sesuai Harapan, Mulai Berkembang 5 anak (1\%), dan katagori Belum Berkembang 10 anak (50\%) pada aspek kelincahan pada tubuh anak.

Selanjutnya, rekapitulasi pra tindakan digambarkan pada tabel berikut : 
Tabel 4. Rekapitulasi Pra Tindakan

\begin{tabular}{|c|c|c|c|c|c|c|c|}
\hline \multirow{2}{*}{ Katagori } & \multicolumn{6}{|c|}{ Aspek yang Diamati } & \multirow{2}{*}{\begin{tabular}{c} 
Rata \\
\cline { 2 - 8 }
\end{tabular}} \\
\cline { 2 - 8 } & \multicolumn{2}{|c|}{$\begin{array}{c}\text { Aspek } \\
\text { keseimbangan }\end{array}$} & $\begin{array}{c}\text { Aspek } \\
\text { kekuatan } \\
\text { tubuh }\end{array}$ & $\begin{array}{c}\text { Aspek } \\
\text { kelincahan } \\
\text { tubuh }\end{array}$ & $\begin{array}{c}\text { Rata } \\
\%\end{array}$ \\
\cline { 2 - 7 } & $\mathrm{F}$ & $\%$ & $\mathrm{~F}$ & $\%$ & $\mathrm{~F}$ & $\%$ & \\
\hline Berkembang Sangat Baik & 1 & 10 & 1 & 5 & 2 & 10 & 6,7 \\
\hline Berkembang Sesuai Harapan & 2 & 25 & 3 & 15 & 3 & 15 & 13,3 \\
\hline Mulai Berkembang & 1 & 30 & 4 & 20 & 5 & 25 & 16,7 \\
\hline Belum Berkembang & 16 & 35 & 12 & 60 & 10 & 50 & 63,3 \\
\hline Jumlah & 20 & 100 & 20 & 100 & 20 & 100 & 100 \\
\hline
\end{tabular}

Berdasarkan tabel 4., aspek keseimbangan pada anak berada pada katagori Berkembang Sangat Baik, 2 anak (10\%), 2 anak (10\%) katagori Berkembang Sesuai Harapan, katagori Mulai Berkembang 1 anak (5\%), dan 16 anak (30\%) katagori Belum Berkembang. Aspek kekuatan pada tubuh anak, 1 anak (5\%) katagori Berkembang Sangat Baik, 3 anak (15\%) katagori Berkembang Sesuai Harapan, Mulai Berkembang 4 anak (20\%), dan 12 anak (60\%) Belum Berkembang. Aspek kelincahan tubuh anak 1 anak (5\%) kata Mulai Berkembang 4 anak (20\%), dan 12 anak (60\%) Belum Berkembang.

Dengan demikian, persentase yang diperoleh pada pra tindakan sangat rendah. Oleh karena itu, peneliti merasa perlu dengan segera untuk melaksanakan tindakan kelas dengan tujuan untuk meningkatkan kemampuan motorik kasar anak melalui metode pembelajaran motorik.

\section{Hasil Pengamatan Tindakan Siklus I}

Setelah peneliti mulai memberikan tindakan kelas tentang peningkatan kemampuan kemampuan motorik kasar anak melalui metode pembelajaran motorik, ternyata diperoleh hasil yang lebih meningkat dibandingkan pada saat pra tindakan, dapat dilihat pada tabel berikut : 
192 | MUSAWA, Vol. 11 No. 2 Desember 2019 : 165 - 201

Tabe1 5 Aspek Keseimbangan

\begin{tabular}{|c|c|c|}
\hline Katagori & Frekuensi $(\mathrm{f})$ & Persentase $(\%)$ \\
\hline Berkembang Sangat Baik & 3 & 15 \\
\hline Berkembang Sesuai Harapan & 5 & 1 \\
\hline Mulai Berkembang & 2 & 50 \\
\hline Belum Berkembang & 10 & 100 \\
\hline Jumlah & 20 & 10 \\
\hline
\end{tabular}

Berdasarkan tabel 5, terdapat 3 anak (15\%) dalam katagori Berkembang Sangat Baik, 5 anak (1\%) dalam katagori Berkembang Sesuai Harapan, katagori Mulai Berkembang 2 anak (10\%) dan Belum Berkembang 10 anak (50\%) pada penilaian peningkatan aspek keseimbangan.

Tabel 6 Aspek Kekuatan Tubuh

\begin{tabular}{|c|c|c|}
\hline Katagori & Frekuensi ( f ) & Persentase (\%) \\
\hline Berkembang Sangat Baik & 4 & 20 \\
\hline Berkembang Sesuai Harapau & 5 & 25 \\
\hline Mulai Berkembang & 4 & 20 \\
\hline Belum Berkembang & 7 & 35 \\
\hline Jumlah & 20 & 100 \\
\hline
\end{tabular}

Data yang disajikan tabel 6, terdapat 4 anak (20\%) dalam katagori Berkembang Sangat Baik, Berkembang Sesuai Harapan 5 anak (25\%), katagori Mulai Berkembang 4 anak (20\%), dan katagori Belum Berkembang 7 anak (35\%) pada penilaian peningkatan aspek kekuatan tubuh anak.

Tabe1 7 Aspek Kelincahan Tubuh Anak

\begin{tabular}{|c|c|c|}
\hline Katagori & Frekuensi ( f ) & Persentase (\%) \\
\hline Berkembang Sangat Baik & 4 & 20 \\
\hline Berkembang Sesuai Harapan & 7 & 35 \\
\hline Mulai Berkembang & 4 & 20 \\
\hline
\end{tabular}




\begin{tabular}{|c|c|c|}
\hline Belum Berkembang & 5 & 25 \\
\hline Jumlah & 20 & 100 \\
\hline
\end{tabular}

Gambaran data pada tabel 7, terdapat 4 anak (20\%) katagori Berkembang Sangat Baik, 7 anak (35\%) Berkembang Sesuai Harapan, katagori Mulai Berkembang 4 anak (20\%), dan katagori Belum Berkembang 5 anak (25\%) pada pengamatan aspek kelincahan tubuh anak. Selanjutnya, rekapitulasi siklus I digambarkan pada tabel berikut :

Tabel 8 Rekapitulasi Tindakan Siklus I

\begin{tabular}{|c|c|c|c|c|c|c|c|}
\hline \multirow{3}{*}{ Katagori } & \multicolumn{6}{|c|}{ Aspek yang Diamati } & \multirow{3}{*}{$\begin{array}{c}\text { Rata } \\
\text { Rata } \\
\%\end{array}$} \\
\hline & \multicolumn{2}{|c|}{$\begin{array}{c}\text { Aspek } \\
\text { keseimbangan } \\
\text { Tubuh }\end{array}$} & \multicolumn{2}{|c|}{$\begin{array}{c}\text { Aspek } \\
\text { kekuatan } \\
\text { tubuh }\end{array}$} & \multicolumn{2}{|c|}{$\begin{array}{c}\text { Aspek } \\
\text { kelincahan } \\
\text { tubuh }\end{array}$} & \\
\hline & $\mathrm{F}$ & $\%$ & $\mathrm{~F}$ & $\%$ & $\mathrm{~F}$ & $\%$ & \\
\hline Berkembang Sangat Baik & 3 & 15 & 4 & 20 & 4 & 20 & 18,3 \\
\hline Berkembang Sesuai Harapan & 5 & 25 & 5 & 25 & 7 & 35 & 26,7 \\
\hline Mulai Berkembang & 2 & 10 & 4 & 20 & 4 & 20 & 20,3 \\
\hline Belum Berkembang & 10 & 50 & 7 & 35 & 5 & 25 & 36,7 \\
\hline Jumlah & 20 & 100 & 13 & 100 & 13 & 100 & 100 \\
\hline
\end{tabular}

Berdasarkan tabel 8, aspek keseimbangan tubuh. 3 anak (15\%) dalam katagori Berkembang Sangat Baik, 5 anak (1\%) katagori Berkembang Sesuai Harapan, Mulai Berkembang 2 anak (10\%) dan Belum Berkembang 10 anak (50\%). Aspek kekuatan tubuh anak, 4 anak (20\%) katagori Berkembang Sangat Baik, Berkembang Sesuai Harapan 5 anak (25\%), Mulai Berkembang 4 anak (20\%), dan katagori Belum Berkembang 7 anak (35\%). Aspek kelincahan tubuh anak. 4 anak (20\%) katagori Berkembang Sangat Baik, 7 anak (35\%) Berkembang Sesuai Harapan, katagori Mulai Berkembang 4 anak (20\%), dan katagori Belum Berkembang 5 anak (25\%). Dengan demikian, persentase yang diperoleh pada siklus I mulai meningkat walaupun belum sesuai harapan peneliti. Oleh karena itu, penelitian masih dilanjutkan ke siklus berikutnya agar Kemampuan Motorik Kasar 
194 | MUSAWA, Vol. 11 No. 2 Desember 2019 : 165 - 201

Anak meningkat sesuai harapan peneliti. Sebelum penelitian siklus II dilaksanakan, terlebih dahulu dilakukan refleksi siklus I dengan mempelajari beberapa kelemahan yang terjadi.

Peneliti melakukan refleksi terhadap pelaksanaan tindakan siklus I, ada beberapa temuan yang menyebabkan peningkatan kemampuan motorik kasar anak belum meningkat sesuai harapan. Refleksi tersebut dikemukakan dalam tabel berikut:

Tabel 9 Refleksi Tindakan Siklus I

\begin{tabular}{|c|l|l|l|}
\hline No. & \multicolumn{1}{|c|}{ Temuan } & \multicolumn{1}{|c|}{ Faktor penyebab } & \multicolumn{1}{|c|}{ Usulan /Rekomendasi } \\
\hline 1. & $\begin{array}{l}\text { Anak masih sering } \\
\text { keluar masuk kelas } \\
\text { dengan alasan yang } \\
\text { tidak jelas }\end{array}$ & $\begin{array}{l}\text { Anak belum terfokus dan } \\
\text { perhatian pada materi } \\
\text { pembelajaran. }\end{array}$ & $\begin{array}{l}\text { Sebaiknya, anak dibagi } \\
\text { kelompok sesuai tugas yang } \\
\text { akan diberikan, hal ini } \\
\text { mempermudah pengamatan } \\
\text { pada anak saat mengerjakan } \\
\text { tugas }\end{array}$ \\
\hline 2. & $\begin{array}{l}\text { Kemampuan } \\
\text { motorik kasar anak } \\
\text { belum berkembang } \\
\text { sesuai harapan }\end{array}$ & $\begin{array}{l}\text { Guru belum mampu } \\
\text { dasar mengajarnya, serta } \\
\text { kurangnya APE. }\end{array}$ & $\begin{array}{l}\text { Sebaiknya, guru lebih } \\
\text { belajar dalam menerapkan } \\
\text { keterampilan } \\
\text { penyampaian materi harus } \\
\text { menggunakan APE. }\end{array}$ \\
\hline 3. & $\begin{array}{l}\text { Konsentrasi atau } \\
\text { fokus perhatian } \\
\text { anak masih belum } \\
\text { ke pembelajaran. }\end{array}$ & $\begin{array}{l}\text { Peneliti masih jarang } \\
\text { menggunakan metode } \\
\text { pembelajaran motorik }\end{array}$ & $\begin{array}{l}\text { Sebaiknya, peneliti lebih } \\
\text { banyak menggunakan } \\
\text { metode pembelajaran } \\
\text { motorik }\end{array}$ \\
\hline $\begin{array}{l}\text { Suasana kelas ribut } \\
\text { saat tindakan } \\
\text { berlangsung. }\end{array}$ & $\begin{array}{l}\text { Anak masih sering } \\
\text { terjatuh saat bermain } \\
\text { dengan menggunakan } \\
\text { motorik kasar. }\end{array}$ & $\begin{array}{l}\text { Sebaiknya, peneliti lebih } \\
\text { mengarahkan anak dalam } \\
\text { melakukan metode } \\
\text { pembelajaran motorik }\end{array}$ \\
\hline
\end{tabular}




\section{Hasil Pengamatan Siklus II}

Setelah peneliti mulai memberikan tindakan kelas tentang peningkatan motorik kasar anak dengan menggunakan metode pembelajaran motorik ternyata diperoleh hasil yang lebih meningkat dibandingkan pada saat siklus I, dapat dilihat pada tabel berikut:

Tabel 10 Aspek keseimbangan tubuh

\begin{tabular}{|c|c|c|}
\hline Katagori & Frekuensi ( f ) & Persentase (\%) \\
\hline Berkembang Sangat Baik & 4 & 20 \\
\hline Berkembang Sesuai Harapan & 9 & 45 \\
\hline Mulai Berkembang & 4 & 20 \\
\hline Belum Berkembang & 3 & 15 \\
\hline Jumlah & 20 & 100 \\
\hline
\end{tabular}

Berdasarkan tabe1 10, terdapat 4 anak (20\%) katagori Berkembang Sangat Baik, 9 anak (45\%) katagori Berkembang Sesuai Harapan, katagori Mulai Berkembang 4 anak (20\%), dan Belum Berkembang 3 anak (15\%) pada pengamatan Aspek keseimbangan tubuh.

\section{Tabel 11 Aspek kekuatan tubuh anak}

\begin{tabular}{|c|c|c|}
\hline Katagori & Frekuensi ( f ) & Persentase (\%) \\
\hline Berkembang Sangat Baik & 5 & 25 \\
\hline Berkembang Sesuai Harapan & 8 & 40 \\
\hline Mulai Berkembang & 4 & 15 \\
\hline Belum Berkembang & 3 & 100 \\
\hline Jumlah & 20 & \\
\hline
\end{tabular}

Data yang disajikan tabe1 11, terdapat 5 anak (25\%) katagori Berkembang Sangat Baik, Berkembang Sesuai Harapan 8 anak (40\%), katagori Mulai Berkembang 4 anak (20\%), Belum Berkembang 3 anak (15\%) pada pengamatan Aspek kekuatan tubuh anak. 
196 | MUSA WA, Vol. 11 No. 2 Desember 2019 : 165 - 201

Tabel 12 Aspek Kelincahan Tubuh Anak

\begin{tabular}{|c|c|c|}
\hline Katagori & Frekuensi ( f ) & Persentase (\%) \\
\hline Berkembang Sangat Baik & 5 & 25 \\
\hline Berkembang Sesuai Harapan & 8 & 40 \\
\hline Mulai Berkembang & 4 & 20 \\
\hline Belum Berkembang & 3 & 100 \\
\hline Jumlah & 20 & \\
\hline
\end{tabular}

Gambaran data pada tabel 12, terdapat 5 anak (25\%) katagori Berkembang Sangat Baik, 8 anak (40\%) Berkembang Sesuai Harapan, katagori Mulai Berkembang 41 anak (20\%), dan katagori Belum Berkembang 3 anak (15\%) pada pengamatan Aspek kelincahan tubuh anak. Selanjutnya, rekapitulasi siklus II digambarkan pada tabel berikut :

Tabel 13 Rekapitulasi Siklus II

\begin{tabular}{|c|c|c|c|c|c|c|c|}
\hline \multirow{3}{*}{ Katagori } & \multicolumn{6}{|c|}{ Aspek yang Diamati } & \multirow{3}{*}{$\begin{array}{c}\text { Rata } \\
\text { Rata } \\
\%\end{array}$} \\
\hline & \multicolumn{2}{|c|}{$\begin{array}{c}\text { Aspek } \\
\text { keseimbangan } \\
\text { Tubuh }\end{array}$} & \multicolumn{2}{|c|}{$\begin{array}{c}\text { Aspek } \\
\text { kekuatan } \\
\text { tubuh }\end{array}$} & \multicolumn{2}{|c|}{$\begin{array}{c}\text { Aspek } \\
\text { kelincahan } \\
\text { tubuh }\end{array}$} & \\
\hline & $\mathrm{F}$ & $\%$ & $\mathrm{~F}$ & $\%$ & $\mathrm{~F}$ & $\%$ & \\
\hline Berkembang Sangat Baik & 4 & 20 & 4 & 20 & 5 & 25 & 21,7 \\
\hline Berkembang Sesuai Harapan & 9 & 45 & 8 & 40 & 8 & 40 & 41,6 \\
\hline Mulai Berkembang & 4 & 20 & 5 & 25 & 4 & 20 & 21,7 \\
\hline Belum Berkembang & 3 & 15 & 3 & 15 & 3 & 15 & 15 \\
\hline Jumlah & 20 & 100 & 20 & 100 & 20 & 100 & 100 \\
\hline
\end{tabular}

Berdasarkan tabe1 13, Aspek keseimbangan tubuh, 4 anak (20\%) katagori Berkembang Sangat Baik, 9 anak (45\%) katagori Berkembang Sesuai Harapan, katagori Mulai Berkembang 4 anak (20\%), dan Belum Berkembang 3 anak (15\%). Aspek kekuatan tubuh anak, 5 anak (25\%) katagori Berkembang Sangat Baik, 
Berkembang Sesuai Harapan 8 anak (40\%), katagori Mulai Berkembang 4 anak (20\%), Belum Berkembang 3 anak (15\%). Aspek kelincahan tubuh anak, 5 anak (25\%) katagori Berkembang Sangat Baik, 8 anak (40\%) Berkembang Sesuai Harapan, katagori Mulai Berkembang 41 anak (20\%), dan katagori Belum Berkembang 3 anak (15\%). Dengan demikian, persentase yang di peroleh pada tindakan siklus II sudah meningkat sesuai harapan. Oleh karena itu, peneliti dan pengamat memutuskan tidak melanjutkan tindakan ke siklus III, karena anak yang belum berkembang tinggal beberapa orang. Refleksi siklus II dikemukakan dalam tabel berikut:

Tabe1 14 Refleksi Tindakan Siklus II

\begin{tabular}{|c|l|l|l|}
\hline No. & \multicolumn{1}{|c|}{ Kelemahan } & \multicolumn{1}{|c|}{ Faktor penyebab } & \multicolumn{1}{c|}{ Rekomendasi } \\
\hline 1. & $\begin{array}{l}\text { Masih ada anak yang } \\
\text { tidak mau masuk kelas } \\
\text { saat tindakan } \\
\text { berlangsung. }\end{array}$ & $\begin{array}{l}\text { Anak tersebut merasa } \\
\text { metode pembelajaran } \\
\text { motorik yang diterapkan } \\
\text { masih kurang. }\end{array}$ & $\begin{array}{l}\text { Peneliti harus sering } \\
\text { menggunakan metode } \\
\text { pembelajaran motorik }\end{array}$ \\
\hline $\begin{array}{l}\text { 2. } \\
\text { Masih ada anak yang } \\
\text { belum fokus pada } \\
\text { materi pembelajaran. }\end{array}$ & $\begin{array}{l}\text { Peneliti tidak } \\
\text { mengarahkan anak untuk } \\
\text { memperhatiklan ketikan } \\
\text { guru menggunakan metode } \\
\text { pembelajaran motorik }\end{array}$ & $\begin{array}{l}\text { Sebaiknya, peneliti } \\
\text { kengarahkan anak } \\
\text { menggunakan metode } \\
\text { pembelajaran motorik }\end{array}$ \\
\hline
\end{tabular}

\section{Pembahasan}

Berdasarkan observasi yang telah dilakukan mulai dari pra tindakan, siklus I sampai pada siklus II dapat dibahas, sebagai berikut :

\section{Pra Tindakan}

Banyak teori yang mendasari bahwa kemampuan motorik kasar termasuk dalam kemampuan dasar anak usia dini yang perlu di tingkatkan. Salah satunya, Suryani menyatakan bahwa "Metode pembelajaran motorik adalah suatu strategi kegiatan pengembangan dengan cara memberikan pengalaman belajar melalui perbuatan melihat dan medengarkan yang diikuti dengan meniru pekerjaan yang 
198 | MUSAWA, Vol. 11 No. 2 Desember 2019 : 165 - 201

didemonstrasikan dalam hal ini kegiatan yang dapat meningkatkan motorik kasar anak.

Berdasarkan refleksi awal dari hasil observasi pra tindakan belum semua anak memiliki kemampuan mototik kasar. Hal ini dapat dilihat pada tabel 4, dari 20 anak yang menjadi subyek penelitian, aspek keseimbangan tubuh katagori Berkembang Sangat Baik, 2 anak (10\%), 2 anak (10\%) katagori Berkembang Sesuai Harapan, katagori Mulai Berkembang 1 anak (5\%), dan 16 anak (30\%) katagori Belum Berkembang. Aspek lompat (kekuatan tubuh), 1 anak (5\%) katagori Berkembang Sangat Baik, 3 anak (15\%) katagori Berkembang Sesuai Harapan, Mulai Berkembang 4 anak (20\%), dan 12 anak (60\%) Belum Berkembang. Aspek kelincahan tubuh, 2 anak (10\%) katagori Berkembang Sangat Baik, 3 anak (15\%) Berkembang Sesuai Harapan, Mulai Berkembang 5 anak (1\%), dan katagori Belum Berkembang 10 anak (50\%).

Data tersebut, menunjukkan bahwa peningkatan kemampuan motorik kasar anak belum berkembang sesuai harapan. Hasil praktek langsung anak pada klegiatan bermain anak belum menunjukkan peningkatan, terlihat dari kemampuan anak saat mengikuti pembelajaran melalui metode pembelajaran motorik. Hal ini disebabkan karena kurangnya menmggunakan metode pembelajaran motorik dimana ketikan metode pembelajaran motorik digunakan dapat membantu peningkatan kemampuan motorik kasar anak dan kurangnya kemampuan peneliti dalam mengajar serta kurangnya pemberian pujian yang dapat memotivasi anak dalam mengikuti pembelajaran. Hal tersebut, memotivasi peneliti untuk melakukan perbaikan pembelajaran dengan melaksanakan tindakan kelas di siklus I. Melalui metode pembelajaran motorik diharapkan dapat meningkatkan kemampuan motorik kasar anak.

\section{Tindakan Siklus I}

Kemampuan motorik kasar pada setiap anak mengalami perbedaan, ada anak yang mengalami kemampuan motoriknya sangat baik seperti yang dialami para atlet, tetapi ada anak yang mengalami keterbatasan.

Berdasarkan tabel 5 dari 20 anak yang menjadi subyek penelitian, aspek keseimbangan tubuh anak, 3 anak (15\%) katagori Berkembang Sangat Baik, 5 anak 
(1\%) Berkembang Sesuai Harapan, katagori Mulai Berkembang 2 anak (10\%) dan Belum Berkembang 10 anak (50\%). Aspek kelkuatan tubuh anak, 4 anak (20\%) katagori Berkembang Sangat Baik, Berkembang Sesuai Harapan 5 anak (25\%), Mulai Berkembang 4 anak (20\%), dan katagori Belum Berkembang 7 anak (35\%). Aspek kelincahan tubuh anak. 4 anak (20\%) katagori Berkembang Sangat Baik, 7 anak (35\%) Berkembang Sesuai Harapan, katagori Mulai Berkembang 4 anak (20\%), dan katagori Belum Berkembang 5 anak (25\%).

Melalui data tersebut, secara umum sudah menunjukkan peningkatan dari tiga aspek yang diamati, jika dibandingkan dengan pra tindakan, walaupun belum berkembang sesuai harapan. Adapun faktor menyebabkan adanya peningkatan kemampuan anak tersebut, adalah pemberian tugas kepada anak melalui metode pembelajaran motorik yang bervariasi dan banyak pilihan permainannya, sehingga membuat anak lebih tertarik dan terfokus untuk mengikuti kegiatan pembelajaran. Selain itu, peneliti selalu memberikan contoh tugas yang akan dikerjakan anak sampai anak memahaminya. Agar anak tidak bosan saat tindakan berlangsung selalu diselingi dengan bernyanyi atau mengucap yel-yel, berbagai macam tepuk yang sudah dihafal anak.

\section{Tindakan Siklus II}

Tindakan siklus II menunjukkan peningkatan yang sangat baik jika dibandingkan dengan siklus I. Peningkatan tersebut dapat dilihat pada tabel 13, dari 20 anak yang menjadi subyek penelitian, aspek keseimbangan tubuh anak, 4 anak (20\%) katagori Berkembang Sangat Baik, 9 anak (45\%) katagori Berkembang Sesuai Harapan, katagori Mulai Berkembang 4 anak (20\%), dan Belum Berkembang 3 anak (15\%). Aspek kekuatan tubuh anak, 5 anak (25\%) katagori Berkembang Sangat Baik, Berkembang Sesuai Harapan 8 anak (40\%), katagori Mulai Berkembang 4 anak (20\%), Belum Berkembang 3 anak (15\%). Aspek kelincahan tubuh anak, 5 anak (25\%) katagori Berkembang Sangat Baik, 8 anak (40\%) Berkembang Sesuai Hardpan, katagori Mulai Berkembang 41 anak (20\%), dan katagori Belum Berkembang 3 anak (15\%).

Setelah melihat hasil tindakan siklus II, kemampuan anak motorik kasar anak meningkat sesuai harapan. Beberapa faktor penyebab kemampuan anak 
200 | MUSAWA, Vol. 11 No. 2 Desember 2019 : 165 - 201

meningkat dengan baik, yakni dalam pelaksanaan tindakan, peneliti menggunakan metode pembelajaran motorik yang lebih bervariasi, membagi anak dalam kelompok kecil, memberikan bimbingan, serta pujian kepada semua anak dalam mengerjakan tugas. Dan sebelum kegiatan pembelajaran dimulai, peneliti selalu menyampaikan aturan kelas, supaya saat kegiatan pembelajaran berlangsung, anak tidak keluar masuk kelas dengan tujuan yang tidak jelas. Melihat peningkatan kemampuan anak tersebut, peneliti dan pengamat memutuskan untuk tidak melanjutkan tindakan ke siklus III, karena hasil pengamatan siklus II ini meningkat dengan baik dan sesuai dengan tujuan penelitian yang telah ditetapkan sebelumnya, yaitu untuk meningkatkan kemampuan motorik kasar anak melalui metode pembelajaran motorik di RA DWP IAIN Palu

\section{DAFTAR PUSTAKA}

Barnawi, Novan Ardi Wiyani, Format PAUD. Cet.2; Jogjakarta: AR-Ruzz Media, 2016

Danim Sudarman, Perkembangan Peserta Didik, Cet.IV; Bandung: Alfabeta,2014

Dariyo Agoes, Psikologi Perkembangan Anak Tiga Tahun Pertama, Bandung: PT Refika Aditama, 2007

Dariyo Agoes, Psikologi Perkembangan Remaja, Cet,1; Bogor: Ghalia Indonesia, 2004

Dimyati Johni, metodologi penelitian pendidikan dan aplikasinya pada pendidikan anak usia dini (PAUD). Cet. 2; Jakarta: Kencana, 2014

Dwijawiata, mari bermain permainan kelompok untuk anak, Cet.1; Yogyakarta: Kanisius, 2013

Fadlilah Muhammad, Desain Pembelajaran Paud, Cet,III; Jakarta: Ar Ruzz Media 2006

Hurlock B.Elizabeth, , Perkembangan Anak jilid I. Terjemahan: (Med Meitasari Tjandrasa bad Muchlihah Zarkasih). Jakarta: PT. Gelora Aksara Pratama., 2006

, Perkembangan Anak, Cet.1 ; Jakarta:Erlangga,2006

https://kbbi.web.id/metode, diakses 2018. 
Kasmiati, Penerapan Metode Pembelajaran Motorik ... | 201

John W. Santrock, Life-Span Development (Perkembangan Masa Hidup),: Edisi;5, Jakarta: Erlangga, 2002 , Perkembangan Anak, Cet.1;Jakarta:Erlangga,2007

PERMENDIKBUD nomor 137 tahun 2014, Tentang Standar Nasional Pendidikan Anak Usia Dini.

Samsudin, Pembelajaran Motorik di Taman Kanak-kanak, Jakarta: Litera Prenada Media Group, 2008

Sudjiono Anas, Dasar-dasar statistik pendidikan, Jakarta: Gramedia, 1989

Suyadi, Psikologi Belajar Paud, Cet. 3; Yogyakarta: PT Pustaka Insan Madani, 2010

Syah Muhibbin, Psikologi Belajar, Cet. 12; Surabaya: Remaja Pendidikan,2012

Ulfah, Suyadi, Maulidya Konsep Dasar PAUD, Cet. 3; Bandung: PT.Remaja Rosda Karya, 2015 